Situs Jurnal : http://ejurnal.stiepancasetia.ac.id/index.php/jieb

Jilid 4 Nomor 2 Juli 2018

Hal 151 - 159

\title{
ANALISIS PENGARUH MOTIVASI INTRINSIK DAN EKSTRINSIK TERHADAP KINERJA KARYAWAN PT. PERMATA FINANCE BANJARMASIN
}

\begin{abstract}
Abdul Kadir*
Abstract: This study aims to determine whether there is influence of intrinsic and extrinsic motivation on the performance of employees of PT. Permata Finance Banjarmasin either partially or simultaneously. The method used in this study is quantitative research is a research model that requires the existence of the calculation of the numbers, while the approach used is a survey approach that is the research that takes samples from the population and use the questionnaire as the main data collection tool. The results of this study indicate that intrinsic and extrinsic innovation have significant influence and change in the direction of employee performance of PT. Permata Finance Banjarmasin. This means that if the level of influence intrinsic and extrinsic motivation perceived higher, then resulted in a higher level of employee performance.
\end{abstract}

Keywords: motivation,iIntrinsic, exstrinsic, performance

Abstrak: Penelitian ini bertujuan untuk mengetahui ada tidaknya pengaruh motivasi intrinsik dan ekstrinsik terhadap kinerja karyawan PT. Permata Finance Banjarmasin baik secara parsial maupun simultan. Metode yang digunakan dalam penelitian ini adalah penelitian kuantitatif yaitu suatu model penelitian yang mengharuskan akan adanya perhitungan angkaangka, sedangkan pendekatan yang digunakan adalah dengan pendekatan survei yaitu penelitian yang mengambil sampel dari populasi dan menggunakan kuesioner sebagai alat pengumpulan data yang pokok. Hasil penelitian ini menunjukan bahwa motovasi intrinsic dan ekstrinsik berpengaruh secara siginifikan dan perubahannya berubah searah dengan kinerja karyawan PT. Permata Finance Banjarmasin. Artinya jika tingkat pengaruh motivasi intrinsic dan ekstrinsik yang dirasakan makin tinggi, maka mengakibatkan makin tinggi juga tingkat kinerja karyawan

Kata kunci : motivasi, intrinsik, exstrinsik, kinerja

\section{Latar Belakang}

Perusahaan merupakan alat dari badan usaha untuk mencapai tujuan yaitu mencari keuntungan dengan menjual barang atau jasa kepada masyarakat. Setiap perusahaan yang berdiri dan beroperasi pasti memiliki tujuan yang ingin dicapai, baik itu tujuan jangka pendek maupun tujuan jangka panjang. Tujuan-tujuan tersebut harus dicapai oleh perusahaan agar mereka mampu mempertahankan keberadaannya dalam dunia usaha dan tidak tergeser oleh pesaing-pesaing lainnya. Salah satu hal yang dapat ditempuh perusahaan agar mampu bertahan dalam persaingan yang ketat yaitu dengan pemanfaatan sumber daya manusia.

Sumber daya manusia merupakan aset penting dalam suatu organisasi, karena merupakan sumber yang mengendalikan perusahaan serta mempertahankan dan mengembangkan perusahaan dalam menghadapi berbagai tuntutan zaman, oleh karena itu 
sumber daya manusia harus diperhatikan, dijaga dan dikembangkan (Wibowo dan Susilowati, 2010).

Sumber daya manusia merupakan salah satu sumber daya yang ada dalam suatu perusahaan/organisasi disamping sumber daya yang lain, misalnya modal, material, mesin dan teknologi. Dewasa ini semakin disadari oleh banyak pihak bahwa dalam menjalankan roda suatu perusahaan/organisasi, manusia merupakan unsur terpenting. Hal ini karena manusialah yang mengelola sumber daya lainnya yang ada dalam perusahaan/organisasi, sehingga menjadi bermanfaat dan tanpa adanya sumber daya manusia maka sumber daya lainnya menjadi tidak berarti. Mengingat bahwa sumber daya manusia merupakan unsur terpenting, maka pemeliharaan hubungan yang kontinyu dan serasi dengan para pegawai dalam suatu perusahaan/organisasi menjadi sangat penting.

Motivasi merupakan dasar bagi kebanyakan orang menjadi pegawai pada suatu organisasi tertentu adalah untuk mencari nafkah. Berarti apabila di satu pihak seseorang menggunakan pengetahuan, keterampilan, tenaga dan sebagian waktunya untuk berkarya pada suatu organisasi, di lain pihak ia mengharapkan menerima imbalan tertentu.

Untuk mendapatkan sumber daya manusia yang diharapkan oleh organisasi agar memberikan andil positif terhadap semua kegiatan perusahaan dalam mencapai tujuannya, setiap pegawai diharapkan memiliki motivasi kerja yang tinggi sehingga nantinya akan meningkatkan kinerja yang tinggi.

\section{Kajian Literatur}

Motivasi merupakan hal yang sangat penting untuk diperhatikan oleh pihak manajemen bila mereka menginginkan setiap pegawai dapat memberikan kontribusi positif terhadap pencapaian tujuan perusahaan. Karena dengan motivasi, seorang pegawai akan memiliki semangat yang tinggi dalam melaksanakan tugas yang dibebankan kepadanya. Tanpa motivasi, seorang pegawai tidak dapat memenuhi tugasnya sesuai standar atau bahkan melampaui standar karena apa yang menjadi motif dan motivasinya dalam bekerja tidak terpenuhi. Sekalipun seorang pegawai memiliki kemampuan operasional yang baik bila tidak memiliki motivasi dalam bekerja, hasil akhir dari pekerjaannya tidak akan memuaskan.

Menurut Wirawan, (2013:699-700) perasaan dan sikap positif atau negative pegawai terhadap pekerjaannya membawa implikasi pengaruh terhadap dirinya dan organisasi. Jika orang puas terhadap pekerjaannya, ia menyukai dan termotivasi untuk melaksanakan pekerjaannya dan kinerjanya tinggi. Jika tidak puas dengan pekerjaannya, tidak termotivasi untuk melaksanakan pekerjaannya dan kinerjanya rendah.

Faktor motivasi memiliki hubungan yang secara langsung dengan kinerja individual pegawai. Motivasi merupakan daya pendorong yang merangsang pegawai untuk mau bekerja dengan segiat-giatnya, berbeda dengan pegawai satu dengan pegawai yang lainnya. Perbedaan ini disebabkan oleh perbedaan motivasi, tujuan, kebutuhan dari masing-masing pegawai untuk bekerja dan karena perbedaan waktu dan tempat.

Motivasi dapat berasal dari motivasi dalam diri (intrinsik) pegawai dan motivasi berasal dari luar pegawai (ekstrinsik). Hal tersebut dapat berpengaruh pada kinerja pegawai di dalam perusahaan. Salah satu hal yang dapat dilakukan manajer untuk memotivasi bawahannya adalah dengan memberikan reward. Agar pengaruh reward dapat digunakan secara maksimal, manajer perlu menghormati keberagaman dan perbedaan individu, Secara jelas memahami apa yang orang lain inginkan dari suatu pekerjaan dan Mengalokasikan rewards untuk memuaskan kebutuhan individu dan organisasi.

Mengingat pentingnya motivasi, maka wujud perhatian pihak manajemen mengenai masalah motivasi pegawai dalam bekerja ialah melakukan usaha dengan jalan memberi motivasi pada pegawai di perusahaan melalui serangkaian usaha tertentu sesuai dengan kebijakan perusahaan, sehingga motivasi pegawai dalam bekerja akan tetap terjaga. Untuk 
memotivasi pegawai, pimpinan perusahaan harus mengetahui motif dan motivasi yang diinginkan oleh para pegawai. Satu hal yang harus dipahami bahwa orang mau bekerja karena mereka ingin memenuhi kebutuhannya, baik kebutuhan yang disadari maupun kebutuhan yang tidak disadari, berbentuk materi atau non materi, kebutuhan fisik maupun rohaniah. Pemberian motivasi ini banyak macamnya seperti pemberian kompensasi yang layak dan adil, pemberian penghargaan dan sebagainya. Hal ini dimaksudkan agar apapun yang menjadi kebutuhan pegawai dapat terpenuhi lalu diharapkan para pegawai dapat berkerja dengan baik dan merasa senang dengan semua tugas yang diembannya. Setelah pegawai merasa senang dengan pekerjaannya, para pegawai akan saling menghargai hak dan kewajiban sesama pegawai sehingga terciptalah suasana kerja yang kondusif, pada akhirnya pegawai dengan bersungguh-sungguh memberikan kemampuan terbaiknya dalam menjalankan tugas dan tanggung jawabnya, dan ini berarti disiplin kerjalah yang akan ditunjukan oleh para pegawai, karena termotivasi dalam melaksanakan tugasnya dalam perusahaan.

Begitu pentingnya peran SDM dalam menentukan keberhasilan perusahaan, maka organisasi harus mampu mewujudkan keinginan dan kebutuhan pegawai melalui pemberian motivasi sehingga dapat mencapai kinerja yang tinggi. Setiap manajer perlu memprediksi adanya usaha pengembangan keterampilan dan kemampuan manajerial untuk memberikan motivasi kepada bawahannya. Manajer memiliki tanggung jawab dalam membantu dan mempengaruhi tingkah laku bawahannya agar mereka dapat melaksanakan tugas secara efektif dan efisien. Dengan demikian keberhasilan manajer memotivasi bawahannya tergantung pada bagaimana manajer memahami motif para pegawainya. Dalam hal ini, perusahaan bukan saja mengharapkan pegawai mampu, cakap dan terampil, tetapi yang terpenting mereka mau bekerja giat dan berkeinginan untuk mencapai hasil kinerja yang maksimal (Hasibuan, 2007).

Motivasi intrinsik timbul dari dalam diri individu sendiri tanpa ada paksaan atau dorongan orang lain, melainkan atas dasar kemauan sendiri. Motivasi intrinsik adalah pendorong kerja yang bersumber dari dalam diri pekerja sebagai individu berupa kesadaran mengenai pentingnya atau manfaat atau makna pekerjaan yang dilaksanakannya (Nawawi, 2001). Jadi motivasi intrinsik adalah motivasi yang berasal dari perasaan puas dalam melaksanakan pekerjaan itu sendiri. Ia merupakan bagian langsung dari kandungan kerja. Oleh sebab itu, menurut Siagian (2004:139) motivasi intrinsic bersumber dari dalam individu.

Motivasi intrinsik jika dihubungkan dengan hirarki kebutuhan manusia, maka menyangkut kebutuhan tingkat lebih tinggi (higher level needs) yaitu esteem needs dan self actualization needs. Nilai kerja intrinsik adalah nilai kerja yang berhubungan dengan pekerjaan itu sendiri. Nilai kerja intrinsik meliputi ketertarikan terhadap pekerjaan, tertantang pada pekerjaan, belajar hal baru, membuat kontribusi penting, memanfaatkan potensi kerja sepenuhnya, tanggung jawab otonomi dan kreatif. Motivasi intrinsik ada untuk posisi ketertarikan dan ketertantangan dalam pekerjaan. Sedangkan motivasi ekstrinsik adalah motivasi yang ada kaitannya dengan imbalan yang diterima seseorang sesudah melakukan pekerjaan. Imbalan ini dapat berupa promosi, hubungan pribadi, gaji, upah, serta tunjangan, sehingga motivasi ekstrinsik ini berasal dari luar pribadi atau individu. Manullang (2001: 119) menyatakan bahwa jika perusahaan menyediakan kondisi-kondisi kerja, upah, tunjangan, atau keselamatan kerja yang tidak mencukupi, maka ia akan mendapat kesulitan dalam menarik pegawai-pegawai yang baik, dan perputaran, kemangkiran serta keluhan-keluhan akan meningkat. Motivasi ekstrinsik bersumber dari luar diri individu sehingga seseorang mau melakukan sesuatu tindakan.

Motivasi ekstrinsik adalah pendorong kerja yang bersumber dari luar diri pekerja sebagai individu berupa suatu kondisi yang mengharuskannya melaksanakan pekerjaan secara maksimal (Nawawi, 2001). 


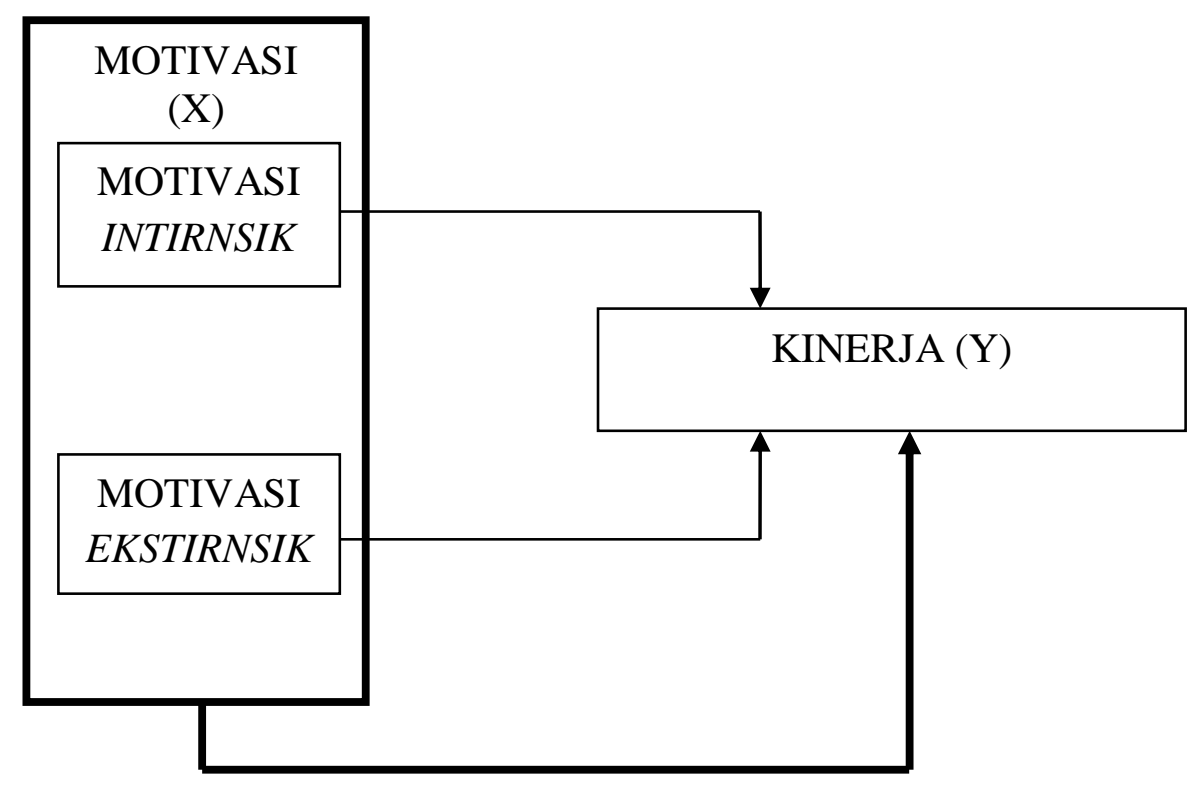

\section{Gambar 1. Model Kerangka Konseptual dan Hipotesis}

Berdasarkan model konseptual pada Gambar 1, maka hipotesis dalam penelitian ini adalah sebagai berikut:

H1: Diduga bahwa motivasi intrinsik dan ekstrinsik berpengaruh signifikan baik secara parsial maupun simultan.

H2: Diduga motivasi intrinsik berpengaruh secara parsial terhadap kinerja.

H3: Diduga motivasi ekstrinsik berpengaruh secara parsial terhadap kinerja.

\section{Metode Penelitian}

Objek penelitian adalah seluruh karyawan yang berkerja pada PT. Permata Finance Cabang Banjarmasin yang berjumlah 30 orang. Teknik pengambilan sampel yang digunakan dalam penelitian ini adalah stratified random sampling. Umar (2003) mengatakan bahwa stratified random sampling merupakan metode pengambilan sampel dengan cara mengelompokkan suatu populasi yang dianggap heterogen menurut suatu karakteristik tertentu ke dalam beberapa subpopulasi sehingga tiap kelompok akan memiliki anggota sampel yang relatif homogen.

Dalam rangka memperoleh data untuk penelitian ini digunakan teknik pengumpulan data adalah :

a. Observasi, merupakan pengumpulan data dengan pengamatan lansung di kantor PT. Permata Finance Banjarmasin.

b. Dokumentasi, yakni data yang didapat dari kantor PT. Permata Finance Cabang Banjarmasin ataupun dari perpustakaan dan internet yang dapat mendukung penelitian ini.

c. Kuisioner, merupakan pengumpulan data yang berisi daftar pertanyaan tertutup yang akan diisi oleh responden.

Data yang telah terkumpul setelah dilakukan uji validitas dan reabilitasnya, akan dianalisis secara kuantitatif deskriftif dan imferensial. Teknik uji validitas dengan menggunakan product moment pearson. Sedangkan untuk uji reabilitas instrumen yaitu dengan melihat nilai Alpha Cronbach. 
Teknik analisis data dengan uji statistik seperti yang di nyatakan dalam rancangan penelitian di muka adalah menguji berdasarkan fungsi didapatkan model analisis regresi berganda, yang akan digunakan dalam penelitian ini, yaitu sebagai berikut:

$\mathrm{Y}=\mathrm{a}+\mathrm{b} 1 \mathrm{X} 1+\mathrm{b} 2 \mathrm{X} 2+\mathrm{e}$

Keterangan :

$\mathrm{Y}=$ Kinerja

$\mathrm{a}=$ Konstanta

b1 = Koefisien regresi dari variabel X1

b2 = Koefisien regresi dari variabel X2

$\mathrm{X} 1$ = Variabel motivasi intrinsik

$\mathrm{X} 2=$ Variabel motivasi ektrinsik

$\mathrm{e}=$ Variabel lain yang tidak termasuk dalam model .

Sebelum dilakukan pengujian dengan analisis regresi, data penelitian diuji dengan uji asumsi klasik yang terdiri dari: uji normalitas, uji heterokedastisitas, dan uji multikolonieritas. Kemudian untuk pengujian hipotesis secara simultan menggunakan Uji $\mathrm{F}$, dan untuk pengujian hipotesis secara parsial menggunakan Uji t. Sedangkan untuk menentukan variabel yang paling dominan mempengaruhi kinerja menggunakan nilai standrdized coefficient beta.

\section{Hasil Penelitian dan Pembahasan}

Proses analisis data pada penelitian ini terdiri dari beberapa tahapan, mulai dari pengecekan validitas dan reliabilitas instrumen penelitian, hingga interpretasi hasil analisis data. Urutan-urutan kegiatannya dijabarkan sebagai berikut:

\section{Uji Validitas}

Uji validitas yang digunakan dalam penelitian ini yaitu dengan mengikuti kaedah product moment pearson (Sutrisno Hadi, 1994) yaitu:

a. Korelasi antar butir dengan faktor harus fositif

b. Peluang ralat $\mathrm{p}$ dari korelasi tersebut minimal $5 \%$

Penelitian ini dilakukan pada seluruh pegawai atau karyawan PT. Permata Finance Cabang Banjarmasin yang berjumlah sebangayak 30 orang. Sebelum melakukan penyebaran kuisioner secara luas, maka terlebih dahulu dilakukan uji Validitas dan Reliabelitas atas instrumen penelitian yang akan digunakan, dalam hal ini kuisioner yang telah disusun.

Uji validitas dengan metode ini, merupakan uji validitas item, dasar kerjanya dengan komputasi korelasi antar setiap item dengan skor total tes sebagai kriteria validitasnya. Adapun hasil yang diperoleh dari uji validitas kuisioner yang dilakukan terhadap 30 responden seperti pada tabel 1 .

\section{Uji Reliabilitas}

Tekhnik uji releabilitas yang digunakan dalam penelitian ini adalah tekhnik analisis dengan menggunakan Alpha Cronbach untuk menunjukan releabilitas, konsistensi internal dan homogenitas antar butir (item) dalam variabel yang diteliti. Langkah ujinya adalah dengan komputasi korelasi antar item, dengan nilai rata-rata korelasinya. Ghozali (2013: 48) mengemukakan bahwa suatu variabel dikatakan reliabel jika memberikan nilai cronbach alpha $>0,60$. Adapun hasil dari uji reliabilitas dapat dilihat pada tabel 2. 
Tabel 1. Hasil Ringkasan Hasil Tes Validitas Kuisioner

\begin{tabular}{ccccc}
\hline Variabel & Butir pertanyaan & $\mathrm{r}$ & $\mathrm{p}$ & Status \\
\hline X1 & $\mathrm{X} 1.1$ & 0.680 & 0,000 & Valid \\
\cline { 2 - 5 } Motivasi Intrinsik & $\mathrm{X} 1.2$ & 0.407 & 0,000 & Valid \\
\cline { 2 - 4 } & $\mathrm{X} 1.3$ & 0.746 & 0,000 & Valid \\
\hline X2 & $\mathrm{X} 2.1$ & 0.579 & 0,000 & Valid \\
\cline { 2 - 4 } Motivasi & $\mathrm{X} 2.2$ & 0.709 & 0,000 & Valid \\
\cline { 2 - 5 } Ekstrinsik & $\mathrm{X} 2.3$ & 0.869 & 0,000 & Valid \\
\hline Y & $\mathrm{Y} 1.1$ & 0.784 & 0,000 & Valid \\
\cline { 2 - 5 } Kinerja & $\mathrm{Y} 1.2$ & 0.755 & 0,000 & Valid \\
\cline { 2 - 5 } & $\mathrm{Y} 1.3$ & 0.941 & 0,000 & Valid \\
\hline
\end{tabular}

Tabel 2. Hasil Ringkasan Test Reabilitas Kuisioner

\begin{tabular}{cccc}
\hline Variabel & Nilai Alpha Cronbach & Nilai Kritis & Status \\
\hline $\mathrm{X} 1:$ Motivasi Intrinsik & 0.599 & 0,60 & Reliabel \\
\hline $\mathrm{X} 2:$ Motivasi Ekstrinsik & 0.778 & 0,60 & Reliabel \\
\hline Y : Kinerja & 0.888 & 0,60 & Reliabel \\
\hline
\end{tabular}

Hasil pada tabel 2 diatas menunjukan bahwa alpha yang distandardisasi untuk semua variabel $\mathrm{X}$ dan Y mempunyai nilai yang lebih besar dari 0,6 dengan demikian maka itemitem pertanyaan seluruhnya bisa dianggap reliabel dalam melakukan fungsinya sebagai alat ukur.

\section{Uji Multikolinearitas}

Tabel 3 . Hasil Uji Multikolinieritas

\begin{tabular}{ccll}
\hline Variabel & Tolerance & VIF & Kesimpulan \\
\hline Motivasi Intrinsit (X1) & .670 & 1.491 & Tidak terjadi multikolinieritas \\
\hline Motivasi Ekstrinsik (X2) & .670 & 1.491 & Tidak terjadi multikolinieritas \\
\hline
\end{tabular}

\section{Uji Autokorelasi}

Untuk dapat mendiagnosis adanya autokorelasi dalam suatu model regresi dilakukan melalui pengujian terhadap nilai uji Durbin-Watson (Uji DW) dengan ketentuan sebagai berikut:

- Jika nilai DW Kurang dari 1,10, maka kesimpulannya Ada Autokorelasi

- Jika nilai DW diantara 1,10 dan 1,54, maka kesimpulannya Tanpa Kesimpulan

- Jika nilai DW diantara 1,55 dan2,46, maka kesimpulannya Tidak Ada Autokrelasi

- Jika nilai DW diantara 2,46 dan 2,90, maka kesimpulannya Tanpa Kesimpulan

- Jika nilai DW Lebih dari 2,91, maka kesimpulannya Ada Autokorelasi

Berdasarkan pengujian yang dilakukan, maka hasil dari pengujianya dapat ditampilkan dalam tabel 4.

Tabel 4. Hasil Uji Autokorelasi

\begin{tabular}{cc}
\hline Nilai DW-hitung & Keputusan \\
\hline 1.820 & Tidak Ada Autokorelasi \\
\hline
\end{tabular}


Hasil dari tabel 4 menunjukan bahwa hasil analisis yang dilakukan koefisien DurbinWatson sebesar 1.820, maka keputusannya bahwa dalam model Regresi tidak ada Autokorelasi.

\section{Analisis Regresi Linear Berganda}

Tabel 5. Hasil Koefisien Regresi Linier

\begin{tabular}{ccc}
\hline Variabel & b & Koefisien Regresi \\
\hline Motivasi Intrinsik (X1) & b1 & .619 \\
\hline Motivasi Ekstrinsik (X2) & b2 & .172 \\
\hline
\end{tabular}

Dari tabel 5 diatas, maka persamaan Regresi yang terbentuk adalah sebagai berikut:

$$
\mathrm{Y}=0,878+0,619 \times 1+0,172 \times 2+e
$$

\section{Uji F}

Teknik uji $\mathrm{F}$ yang dipergunakan yaitu dengan membandingkan antara $\mathrm{F}$ hitung dengan $\mathrm{F}$ tabel, jika $\mathrm{F}$ hitung lebih besar dari $\mathrm{F}$ tabel maka keputusannya adalah $\mathrm{H}_{\mathrm{o}}$ dan $\mathrm{H}_{\mathrm{a}}$ diterima. Dengan tingkat keyakinan 95\% dan derajat kebebasan (k-1) (n-k) maka tabel untuk $\mathrm{F}$ $(0,05)(4)(97)=2,3092$. Perbandingan antara F hitung dengan $F$ tabel dapat dilihat dalam tabel 6.

\section{Tabel 6. Hasil Perbandingan F Hitung dan F Tabel}

\begin{tabular}{ccc}
\hline F Hitung & F Tabel & Sig. \\
\hline 8.447 & 2,3092 & 0,000
\end{tabular}

Sumber: Data Primer yang sudah diolah

Dari tabel 6 ternyata $\mathrm{F}$ hitung lebih besar (8.447) dari $\mathrm{F}$ tabel (2,3092), sehingga keputusannya adalah menolak $\mathrm{H}_{0}$ dan menerima $\mathrm{H}_{\mathrm{a}}$ yang artinya variabel $\mathrm{X} 1$ dan $\mathrm{X} 2$ secara bersama-sama berpengaruh pada kinerja pegawai PT. Permata Finance Cabang Banjarmasin.

\section{Uji t}

Teknik uji $\mathrm{T}$ yang dilakukan yaitu dengan melihat nilai $\mathrm{T}$ signifikan pada hasil pengolahan data melalui SPSS. Dalam penelitian ini $\alpha$ yang digunakan yaitu sebesar 5\% $(0,05)$. Keputusannya, jika nilai $\mathrm{T}$ signifikan $<$ terhadap $\alpha$ maka $\mathrm{H}_{0}$ akan ditolak dan menerima $\mathrm{H}_{\mathrm{a}}$. Berikut disajikan hasil perhitungan $\mathrm{T}$ signifikan masing-masing variabel bebas (kinerja karyawan).

Tabel 7. Hasil Rangkuman Nilai t Signifikan

\begin{tabular}{ccc}
\hline Variabel & Signifikan $\mathrm{t}$ & $\mathrm{H}_{\mathrm{a}}$ diterima/ditiolak \\
\hline Motivasi Intrinsik (X1) & .011 & Diterima \\
\hline Motivasi Ekstrinsik (X2) & .362 & Ditolak \\
\hline
\end{tabular}

Sumber: Data Primer yang sudah diolah.

Dari hasil rangkuman nilai t signifikan pada tabel 7 terlihat bahwa, nilai signifikan $t$ untuk $\mathrm{X} 1=0,011$, artinya X1 (Motivasi Intrinsik) signifikan dalam mempengaruhi Kinerja. Jadi variabel X1 signifikan dalam mempengaruhi $\mathrm{Y}$ atau $\mathrm{H}_{0}$ ditolak dan $\mathrm{H}_{\mathrm{a}}$ diterima. 
Untuk Variabel X2 = 0,362, artinya X2 (Motivasi Ekstrinsik) tidak signifikan dalam mempengaruhi Kinerja. Jadi dapat disimpulkan bahwa $\mathrm{H}_{0}$ diterima dan $\mathrm{H}_{\mathrm{a}}$ ditolak.

Sutrisno Hadi (1996) dalam penjelasannya mengenai kaidah uji hipotesis penelitian, jika hasil peluang ralat $(\mathrm{p})<0,05$ hasilnya dikategorikan cukup signifikan artinya $\mathrm{H}_{0}$ ditolak dan $\mathrm{H}_{\mathrm{a}}$ diterima.

Dari hasil analisis yang dilakukan, diperoleh bahwa variabel Motivasi ekstrinsik dan intrinsic berpengaruh secara siginifikan dan perubahannya berubah searah dengan tingkat Kinerja pegawai PT. Permata Finance Cabang Banjarmasin. Artinya jika tingkat pengaruh motivasi ekstrinsik dan intrinsik yang dirasakan oleh pegawai atau karyawan PT. Permata Finance Cabang Banjarmasin makin tinggi , maka mengakibatkan makin tinggi juga tingkat kinerja Pegawainya.

Selanjutnya dapat disusun persamaan regresi dari hasil penelitian ini. Persamaan regresi yang didapat dari hasil analisis tersebut adalah:

$Y=0,878+0,619 X 1+0,172 \times 2$

Untuk melihat dominasi pengaruh dari variabel bebas terhadap variabel terikatnya, maka bisa dilihat koefisien beta (koefisien regresi baku). Nilai koefisien regresi baku antar variabel bebas dapat dibandingkan, karena nilainya telah distandarisasi sehingga variabel bebas (Motivasi) yang memiliki koefisien regresi baku yang lebih besar, berarti akan memberi pengaruh yang lebih besar pula pada variabel terikatnya.

Hasil pengolahan data penelitian ini, ternyata variabel bebas yang memiliki beta terbesar adalah variabel Motivasi Intrinsik (X1) yaitu sebesar 0,619 (Lihat table 6). Oleh karena itu dapat dikatakan bahwa variabel X1 yang memiliki pengaruh terbesar terhadap kinerja adalah variabel X1 yaitu dengan koefisien regresi baku sebesar 0,619. Hasil pembuktian hipotesa pertama (H1) yaitu keputusannya menolak $\mathrm{H}_{0}$ dan menerima $\mathrm{H}_{\mathrm{a}}$ yang artinya uji $\mathrm{F}$ terhadap persamaan regresi yang diperoleh dari penelitian ini menunjukan hasil bahwa, secara bersama-sama kedua variabel motivasi berpengaruh terhadap tingkat kinerja pegawai PT. Permata Finance Cabang Banjarmasin.

\section{Kesimpulan}

Berdasarkan hasil analisis dan pembahasan maka dapat disimpulkan bahwa terdapat pengaruh motivasi ekstrinsik secara parsial terhadap kinerja pegawai PT. Permata Finance. Sedangkan variabel Motivasi intrinsic tidak berpengaruh terhadap kinerja pegawai.

Untuk saran dalam penelitian ini, disarankan kepada para pembaca yang kebetulan berminat meneliti kasus serupa, sebaiknya mengembangkan permasalahan dan mengembangkan variabel dengan disertai dukungan indikatorindikator yang lebih baik dan handal. Dengan demikian hasil yang diharapkan dapat mengungkap lebih banyak permasalahan dan memberikan temuan-temuan penelitian yang lebih berarti dan bermanfaat bagi banyak pihak.

\section{DAFTAR PUSTAKA}

Bejo, Siswanto. (2005). Manajemen Tenaga Kerja Indonesia PendekatanAdministratif dan Operasional, Jakarta: Bumi Aksara.

Brantas. (2009). Dasar-dasar Manajemen, Bandung: CV Alfabeta.

Djamarah. (2002). Teori Motivasi, edisi 2 (ed-2), Jakarta: PT. Bumi Aksara.

Edi Sutrisno. (2016). Manajemen Sumber Daya Manusia. Jakarta: Prenadamedia Group.

Ghozali, Imam.(2007). Analisis Multivariate Dengan Program SPSS. Cetakan Empat, Semarang: Badan Penerbit Universitas diponegoro. 
Gouzali Saydam. (2005). Manajemen Sumber daya Manusia: Suatu Pendekatan Mikro, Jakarta: Djambaran.

Gomes, Faustino Cardoso, (2003), Manajemen Sumber Daya Manusia, Yogyakarta: Penerbit Andi.

Hasibuan, Malayu S.P. (2002). Manajemen Sumber Daya Manusia, Jakarta: Bumi Aksara.

Innayatullah, Atiya dan Jehangir Palwasha. (2013). Teacher's Job Performance:The Role of Motivation. Abasyn Journal of Social Science. Vol.5. pp. 78-99.

Iskandar. (2008). Metodologi Penelitian Pendidikan dan Sosial (Kuantitatif dan Kualitatif), Jakarta: GP Press.

Luthans, Fred. (2011). Organizational Behavior: An Evidence-Based Approach. McGrawHill. New York.

Manullang.M; (2001). Manajemen Sumber Daya Manusia. Yogyakarta: Andi Offset.

Moeheriono. (2010). Pengukuran Kinerja Berbasis Kompetensi. Bogor: Ghalia Indonesia. Hal. 60.

Nawawi, H. Hadari. (2001). Manajemen Sumber Daya Manusia, Jakarta: Gadjah Mada University Press.

Robbins, S. P. (2006). Perilaku Organisasi, Jakarta: Salemba Empat. 